\title{
The Political Considerations in Chinese Companies' Cross-Border Acquisitions
}

\author{
Shi Li \\ Xiamen National Accounting Institute, Xiamen, China \\ Email address: \\ lishi@xnai.edu.cn \\ To cite this article: \\ Shi Li. The Political Considerations in Chinese Companies' Cross-border Acquisitions. International Journal of Business and Economics \\ Research. Vol. 7, No. 5, 2018, pp. 158-169. doi: 10.11648/j.ijber.20180705.15
}

Received: August 13, 2018; Accepted: September 12, 2018; Published: October 13, 2018

\begin{abstract}
Cross-border acquisition activity led by Chinese enterprises have become increasingly conspicuous and prevalent in recent years. However, many of them were obstructed by foreign governments on the ground of "Threating National Security". Using a sample of 543 cross-border transactions made by China's listed companies from 2000 to 2014, this paper examines whether the acquisition of foreign political sensitive assets, which may threat foreign countries' national security, affect the likelihood of acquisition completion and acquisition performance. We find that central government-owned enterprises are more likely to acquire political sensitive assets than private-owned enterprises and local government-owned enterprises. The political sensitive acquisitions are less likely to be completed than others. The market response of acquisition announcements is significantly greater for political sensitive acquisitions than for other acquisitions, which suggests that political sensitive acquisitions increase shareholders' wealth. Finally, we show that the positive effect of political sensitive acquisitions on shareholders' wealth is stronger for private-owned enterprises than for state-owned enterprises. Overall, our findings suggest that Chinese companies should reduce the political risks of cross-border acquisitions and try to achieve a win-win for the nation, market and enterprises when they implement "go-out" strategy. In academic value, this paper offers a new research angle on cross-border acquisitions, which is the impact of political sensitive target on acquisition transactions.
\end{abstract}

Keywords: Cross-border Merger, Acquisitions, Political Sensitive Assets, Acquisition Performance

\section{Introduction}

Given the fragile economic recovery in developed countries, China ensures rapid yet steady increase in national economy after global financial crisis of 2008. Chinese non-financial outbound direct investment which topped USD 118.02 billion in 2015 , with an increase of $14.7 \%$ year on year, has risen consecutively by an average growth of $33.6 \%$ a year over the past 13 years, according to Ministry of Commerce of PRC. It follows that cross-border mergers and acquisitions have become an important approach for Chinese enterprises to seek the new-round development. Spontaneously, increasing failure rate in cross-border mergers and acquisitions is considerable [1], which reached up to $12 \%$ and $11 \%$ in 2009 and 2010, while the rate in developed countries kept within 2\%, according to Financial Times on Jan. 30, 2011. It also points out that many related cases were turned down by foreign governments for national-security implications. A good example is that Huawei was turned down by American government when merging American companies like 3Leaf in 2011.

It contributes to the continual failures of cross-border mergers and acquisitions that security review to foreign capital acquisition is getting more stringent all around the world in recent years. Canada promulgated the "Canada Investment Act" amendments to review foreign investment that may affect national security in 2005. France listed 11 industries as protected in the same year, then it classed 20 large corporations as special protections against foreign acquisition in 2006. Moreover, America promulgated Foreign Investment and National Security Act (denoted as "FINSA" thereafter), which focused broader national security issues and extended the scope of review in 2007. The Act divided political sensitive assets, which involved national security, into four categories as follows: (1) critical natural resource industries, including energy like coal, petrol and other scarce resources, such as iron ore, rare earths, chemical fertilizer like potash fertilizer, (2) national defense industries, including 
suppliers of uranium, aviation and other departments of national defense, (3) financial industries concerning national economic security and(4) telecommunications industry which refers to national information security.

Based on the definition of political sensitive assets given by FINSA, this article takes 543 cross-border mergers and acquisitions made by China's listed companies from the period 2000 to 2014 as sample and examines the following three issues: Firstly, what kind of enterprises is more likely to acquire overseas political sensitive assets? Secondly, what is the completion rate of acquiring political sensitive assets? Finally, is it positive to enhance shareholder value when carrying out such acquisitions? The answers to three questions could provide not only lessons for Chinese cross-border merges and acquisitions in post financial crisis era, but also theoretical foundations for making more rational regulatory policies in overseas acquisitions.

\section{Literature Review}

Overseas mergers and acquisitions is a significant way for outward direct investments. Domestic and overseas studies are mainly excavating the motivations, success rate and performance of overseas mergers and acquisitions so far. We will have a review towards existing literatures to tease out the three issues mentioned above.

\subsection{The Motivations of Cross-Border $M \& A$}

The motivations of enterprises implementing overseas mergers and acquisitions can be roughly divided into following five categories.

First, to obtain advanced technology. Since technological superiority has become the core factor of corporate competitiveness globally, Li (2003) [2] shows that one of the vital motivations for transnational corporation to implement overseas acquisition is to obtain relevant technology, which will contribute to achieve the static and dynamic synergy of technology by means of international specialization of value chain, after analyzing massive statistical data and cases. Yu and Wang (2008) [3] study the case of Nanjing Auto Corp. acquired Rover UK in 2005 and find that overseas acquisition would facilitate enterprise self-innovation when accumulated knowledge of the target is greater than or complementary to that of the acquirer.

Second, to gain strategic resources. Shao, et al (2012) [4] state that acquisitions aiming to obtain strategic resources are superior to those aiming to obtain advanced technologies and well-known brands in wealth effect, though the market response is significantly positive in both kinds of acquisitions.

Third, to do exchange rate arbitrage. Erel, et al (2012) [5] find that domestic enterprises are more likely to acquire enterprises whose host countries' currency is depreciatory to domestic currency through investigating 56798 transactions worldwide from 1990 to 2007; while Gu and Reed (2011) [6] draw a similar conclusion by analyzing acquisition cases implemented by Chinese enterprises.
Fourth, to increase shareholders' value. Baker et al (2008) [7] find that higher stock market valuation will increase domestic companies' likelihood to implement outwards investment and acquisitions.

Fifth, to diversify industries. Moeller and Schlingemann (2005) [8] demonstrate that industry diversification is one of the motivations of overseas acquisitions while such cases shows negative market response and negative long-term performance, based on U.S. corporate data.

\subsection{Factors Affecting the Success Probability of Cross-Border $M \& A$}

From the literatures, the completion rate of cross-border acquisition is mainly affected by following factors:

First, systematic differences between host and home countries. Dikova et al (2010) [9] indicate larger systematic differences between host and home countries will lead to lower completion rate; Buckley, et al (2007) [10] find political risks of host country play a significant passive influence to Chinese outward direct investment; Zhang and Zhou (2010) [11] claim that institutional quality has no critical impact on the completion rate of Chinese overseas M\&A.

Second, capital control of host country. Desai et al (2006) [12] suggest that deregulation of capital will increase the completion rate of the country's overseas M\&A.

Third, culture differences between host and home countries. Ahern et al (2015) [13] find that culture similarities would facilitate cross-border transactions implemented between two countries in terms of dollar amount and quantity.

Fourth, the proportion of foreign institutional investors shareholding. Ferreira et al (2010) [14] indicate higher foreign institutional investors shareholding will increase companies' possibility to implement cross-border M\&A and success in such transactions.

Fifth, the economic correlation of both parties. Zhang et al (2010) [1] suggest that many factors influence transaction completion, such as the economic correlation between two parties, forms of ownership of the acquirer and target company, overseas M\&A experiences and the employment of professional consultants, etc., given the empirical analysis of 1324 Chinese overseas M\&A cases.

\subsection{Performance of Cross-Border $M \& A$}

The market value of target enterprise would increase to a larger degree if the acquirer executes better corporate governance by Bris and Cabolis (2008) [15]. Moeller and Schlingemann (2005) [8] demonstrate that the performance of American cross-border $M$ \& As as well as domestic ones, which would be suppressed by economic limits of the target country. Gu and Reed (2011) [6] summarize that the market performance is significantly positive in the announcement date of Chinese companies' overseas M\&A events, which reflects market's positive evaluation to Chinese overseas M\&As, while views on overseas M\&A performance vary, after observing the performance of 157 Chinese overseas M\&As from 1994 to 2009 under different time spans. Cheng 
and Zhang (2006) [16] indicate more significant shareholder wealth effect appears in 20 days before and after the transaction announcement and shareholder wealth effect in electronic information industry is remarkably more distinct than that in household appliance industry. Besides, macro-economy of the home country and payment method both influence shareholder wealth effect. Gugler, et al (2003) [17] compared enterprises worldwide which implemented cross-border acquisition with those companies which do not, and see rise in profit while drop in sales income in 1 to 5 year period after the acquisition transaction. However, after dividing the sample into large and small organizations, the above results only hold for large organizations while small enterprises see rise in both profit and sales revenue. The reason for such phenomenon is that small companies achieved economies of scale and economies of scope in certain extent while large corporates enhanced their market power and monopoly degree through merges and acquisitions.

To sum up, there are few researches on overseas mergers and acquisitions of political sensitive assets that involve national security, though many have studied the motivation, completion and financial performance. Many related issues still need to be studied in depth. For example, which kinds of enterprises are more likely to acquire overseas political sensitive assets? What is the completion rate for such mergers? What factors influence transaction completion? How is the financial performance post-acquisition? All the questions above need to be examined. Hence, this article will focus on these questions to continue theoretical analysis and empirical verification, deepening the research on overseas mergers and acquisitions. Therefore, this paper analyzes those questions theoretically and empirically.

\section{Research Hypothesizes}

\subsection{The Influence of Nature of Property Right on Transaction Implementation}

Different countries have successively legislated to limit foreign capital investments in some political sensitive industries which mainly involve scarce resource products, finance institution, military products, critical infrastructures, etc. In this case, are state-owned-enterprises (denoted as "SOE" thereafter) or private-owned-enterprises (denoted as "POE thereafter) more likely to implement overseas political sensitive asset M\&A? We will analyze this issue in depth. In the perspective of business goals, researches show that the aims of SOE are often manipulated by political ends which are different from POE's profit maximization goal $[18,19,20]$. Specifically, when making investment decisions, some papers state that SOE are inclined to achieve government's aspiration than private enterprises $[21,22]$. It meets the global strategic layout of government to acquire overseas political sensitive assets. SOE tend to participate in mergers which meets political objective while with limited economic interest, while POEs will not chasing higher profit. Thus, from the perspective of business goals, we indicate that SOEs are more likely to acquire political sensitive assets than POE after controlling financial and other influencing factors (Hypothesis 1).

\subsection{The Influence of Political Sensitive Assets on Transaction Completion}

We will discuss the influence of acquiring overseas political sensitive assets on transaction completion. It's expected that compare with other targets, political sensitive asset targets are more difficult to be acquired. The reasons are as followed.

Firstly, many countries have modified statutes on foreign mergers and acquisitions supervision recently through their security review system, so as to establish or improve national safety supervision system. The above system may reduce the transaction completion rate. We are going to analyze the latest legislations and practices of national safety supervision system for foreign mergers and acquisitions in major countries. U.S introduced Foreign Investment and National Security Act of 2007 which listed 11 relevant factors of national security that should be taken into account when acquired by foreign capital, such as critical infrastructure (like national defense and finance industry), important technologies (like telecommunication engineering) and key energy resources. German drafted The Foreign Trade and Payments Act in August, 2008 and enforced it on April 24, 2009. ${ }^{1}$ This Act authorized the federal government to control foreign capital holding shares of enterprises related to strategic industries, military projects, cryptology, aviation, railway, energy and banks. Canada established Bill C-59, An Act to amend the Investment Canada $\mathrm{Act}^{2}$, which strictly restricts or forbids foreign investment in four sensitive industries, such as finance (like banks, securities, insurance companies, trust business, etc.), energy (like oil, gas, nuclear energy, etc.), transportation and telecommunication engineering, in 2004. In 2008, Australia issued Summary of Australia's Foreign Investment Policy ${ }^{3}$ that crystallizes cautious approach to mergers and acquisitions involving resource areas when conducting a national interest review. France announced Decree No 2005-1739 dated December 30, 2005 regulating foreign financial relationships, codified under Articles R153-1 et seq. of the French Monetary and Financial Code (the "CMF") and implementing Article L. 151-3 of the CMF to complete national safety supervision system. ${ }^{4}$ The decree stipulates that foreign investors must sign an agreement with the Ministry of Finance and Industry to comply with the access conditions when investing in French sensitive industries,

\footnotetext{
1 Details in The Germany Federal Government, Explanatory Memorandum to Amendment of the Foreign Trade and Payments and the Foreign Trade and Payments Regulation, 2009

2 Details in Bill C-59, An Act to amend the Investment Canada Act. http://www.parl.gc.ca/common/bills 1s.asp?Parl =38\& Ses=1\&ls=c59.

3 Details in Summary of Australia's Foreign Investment Policy. http://www.firb.gov.au/content/_downloads/Genera_Policy

Summary_April 2008.pdf.

4 Details in Decree No 2005-1739 dated December 30, 2005 regulating foreign financial relationships, codified under Articles R153-1 et seq. of the French Monetary and Financial Code (the "CMF") and implementing Article L. 151-3 of the CMF.
} 
including aerospace, biotechnology, cryptology, nuclear, weapons, microelectronics, information system for transmitting sensitive data, etc. The U.K. takes the safety investigation about foreign M\&A in three fields: national defense security, diversification of media and the stabilization of financial industry, mainly according to the chapter of public interest of Enterprise Act 2002. ${ }^{5}$ Through the analysis on foreign M\&A safety supervision standards of the six developed countries mentioned above, it is observed that governments require strict supervisions towards political sensitive industries involving national security though different countries have different focus Therefore, it would be difficult to complete a transaction in these target areas.

Secondly, compare with other western developed countries, Chinese enterprises face stricter safety supervisions by western home countries due to the differences on political system and values, which contributes to higher failure rate. For instance, Alon and McIntyre (2008) [23] raise that China's cross-border mergers and acquisitions are affected by host countries' market forces, government directives, and institutional factors. Rui and Yip (2008) [24] also find that Chinese transnational corporations are constrained by the institutional background of host countries. Globerman and Shapiro (2009) [25] suggest in most cases, Chinese transnational corporations would face greater institutional obstacles when taking overseas M\&A, than other countries due to host countries' concern about the state-owned enterprise background and political goals of Chinese companies. Based on analyses above, we indicate that the transaction completion would be reduced when the target company is political sensitive industry in the host country (Hypothesis 2) ${ }^{6}$

\subsection{The Impacts of Acquiring Overseas Political Sensitive Assets on Share Value}

There are many disputes regarding the impact of mergers and acquisitions on shareholder value. The most weighted is the synergetic benefit theory of mergers and acquisitions, which predicts that there will be " $1+1>2$ " synergies on both sides when there is a synergy between the acquirer and the target $[4,26,27,28]$. We think the synergetic benefit theory can better explain Chinese enterprises' cross-border political sensitive assets. To be specified, there are three main purposes for the acquirer to take over overseas political sensitive assets, especially strategic natural resources, national defense resources, financial institutions and telecommunications

\footnotetext{
5 Details in Overview of Enterprise Act 2002.

http://www.oft.gov.uk/enterpriseact/htm.

6 Theoretically, the supervision system for foreign capital mergers and acquisitions decides the lower success probability of merging political sensitive assets than merging other assets. But the empirical test of this issue still has a certain theoretical value, which shows up in learning about the depth of the difference of success probability between two kinds of mergers and acquisitions and whether there are success probability discrepancies in different political sensitive industries. These empirical evidences will offer the theoretical reference for China's enterprises to choose target companies. Thanks to the reviewer for valuable advice on this issue.
}

companies. Firstly, obtain the nation's urgently needed natural resources and national defense resources; secondly, acquire foreign advanced technologies; thirdly, open access to foreign financial market by acquiring overseas financial institutions like banks. As mentioned above, overseas political sensitive assets are complementary to the acquirer's assets, and thus more likely to generate synergies. Therefore, we propose the third hypothesis that shareholder value will be enhanced to a greater extent when acquiring cross-border political sensitive assets than others (Hypothesis 3).

Furthermore, SOE and POE might be different in obtaining synergies from acquiring overseas political sensitive assets. As introduced above, SOEs are often controlled to deviate from profit maximization goal by various political ends [20]. That is to say state-owned enterprises may acquire political sensitive assets to meet with the government's strategic layout instead of profit maximization. We forecast that the positive effect on shareholder value is significantly weaker in SOEs, compared with POEs, when acquiring overseas political sensitive assets (Hypothesis 4).

\section{Research Methodology}

\subsection{Data Source}

The initial sample is the M\&A events from WIND database between 2000 and 2014. The selection criteria is a Chinese acquirer, i.e. the company's operating business and headquarter are located in mainland China, Hong Kong or Macau makes a cross-border M\&A transaction, which gives us 1122 samples. Then the sample is filtered by following standards: (1) The acquirers are public companies; (2) the transactions are equity acquisitions; (3) the acquirers held no more than $50 \%$ equity of the target companies before the transaction. Moreover, we verified the authenticity and accuracy of the filtered sample by Googling listed company announcements and excluding duplicated and error-recorded transactions, which gives us a final sample size of 543 transactions. Chinese public companies' corporate governance, finance and transaction data are from WIND and CSMAR databases, while overseas companies' data are from COMPUSTAT, company annual reports and the website of each Stock Exchange. Transactions and target company data are from the company disclosure.

\subsection{Variable Definitions}

\subsubsection{Measurement of Political Sensitive $M \& A$}

Sensitive is a dummy variable, which equals 1 if the target company is in political sensitive industry and 0 otherwise. Based on Foreign Investment and National Security Act of 2007 established by the U.S., we defined four kinds of industries as political-sensitive ones: (1) strategic resources, including energy (coal, petroleum and natural gas) and other scarce resources (iron ore, rare earths, chemical fertilizer like potash fertilizer); (2) national defense related industries, including uranium, aviation, former or current military vehicle manufacturers and suppliers of defense related departments); 
(3) finance sector, including insurance, banking, securities and asset management agencies related to the country's economic stability; (4) telecommunication industry which regarded national information security. We build four dummy variables according to the four kinds of political sensitive industries, which are Strategic Resource, Defense Related, Financial Institution and Telecommunication. If the target company is in one of the four political sensitive industries, the corresponding dummy variable is 1 and 0 otherwise.

\subsubsection{Measurement of Transactions Characteristics}

The three transactions characteristics mainly studied in the paper are as follow: (1) Completion: dummy variable to measure whether the transaction is completed, that equals 1 if the transaction is completed and 0 otherwise; (2) CAR: the variable of market response measured by accumulated excess return before and after the first transaction announcement, that is $[-1,+1]$ time window. The accumulated excess return is acquired from the adjustment of market model whose coefficient is estimated by the yield rate of 250 trading days before the first announcement, that is the time window of $[-255,-6]$. The reference of yield rate varies according to the listed market. To be specific, listed companies in mainland China adopt the comprehensive market return with circulation market value weighting and cash bonus considered; listed companies in Hong Kong adopt the daily yield of Hang Seng Index; companies in the U.S. adopt the daily yield of Standard \&Poor's 500 Index and companies in Singapore adopt the daily yield of Straits Times Index.

\subsubsection{Measurement of the Acquirer's Ownership Property}

Considering Chinese reality, we use Karolyi and Liao (2010) [29]'s measurement, divide the acquirers into SOEs and POEs on the nature of the largest shareholder's ultimate controller.
The dummy variable SOE is defined as the value of 1 if the ultimate controller is central, local governments, or their holding institutions, and 0 otherwise. And SOE is further divided into central government-owned (CGO), which the ultimate controller is central government, and its holding institutions and local government-owned (LGO), which the ultimate controller is local governments and their holding institutions that takes the value 1 or 0 otherwise.

\subsubsection{Other Transaction and Firm Characteristics Variables}

This paper inspects the effect of acquiring political sensitive assets on transaction completion and market response through multiple regression analysis. In the regression, we control acquiring firm characteristics, target firm characteristics and transaction characteristics. The control variables related to transactions are: (1) Competitive: if there exist competitors, the variable equals 1 , and 0 otherwise; (2) Toehold: acquirer's shareholding ratio in the target company before implementing the transaction; (3) Friend: if it is a hostile merger and acquisition, that is the acquirer implement the transaction after receiving a formal rejection from the board of the target company[30], Friend values 0 and 1 otherwise; (4) Horizontal: if acquirer and target are in the same industry, Horizontal equals to 1 and 0 otherwise. The industry classification is based on the industry classification standard of the China Securities Regulatory Commission (denoted as "CSRC" thereafter). The manufacturing industry is divided into secondary industries, and the rest of the industries are divided into primary industries; (5) Pay Method: if the transaction is completely settled by cash, the variable is 1 and 0 otherwise. The data of Competitive are collected from related news reports and others are collected from announcements of the M\&A events manually.

Table 1. Variable Descriptive Statistics.

\begin{tabular}{|c|c|c|c|c|c|c|c|}
\hline Variable Name & Variable Symbol & Mean & Medium & Min. & Max. & Sd. & Quantity \\
\hline Political sensitive industries & Sensitive & 0.250 & 0 & 0 & 1 & 0.434 & 543 \\
\hline Strategic resource & Strategic Resource & 0.159 & 0 & 0 & 1 & 0.365 & 543 \\
\hline National defense related & Defense Related & 0.033 & 0 & 0 & 1 & 0.180 & 543 \\
\hline Telecommunications suppliers & Telecommunication & 0.026 & 0 & 0 & 1 & 0.159 & 543 \\
\hline Financial Institution & Financial Institution & 0.035 & 0 & 0 & 1 & 0.184 & 543 \\
\hline Whether the M\&A transaction completed & Completion & 0.827 & 1 & 0 & 1 & 0.379 & 543 \\
\hline Market response & CAR $[-1,+1]$ & 0.017 & 0.005 & -0.227 & 0.252 & 0.074 & 540 \\
\hline State-owned enterprises & SOE & 0.337 & 0 & 0 & 1 & 0.473 & 543 \\
\hline Central government-owned enterprises & CGO & 0.190 & 0 & 0 & 1 & 0.392 & 543 \\
\hline Local government-owned enterprises & LGO & 0.147 & 0 & 0 & 1 & 0.355 & 543 \\
\hline Is there a competitor & Competitive & 0.046 & 0 & 0 & 1 & 0.210 & 541 \\
\hline Acquirer's shareholding before M\&A & Toehold & 0.796 & 0 & 0 & 49.900 & 4.217 & 543 \\
\hline Acquisition attitude & Friend & 0.007 & 0 & 0 & 1 & 0.086 & 543 \\
\hline Horizontal acquisitions or not & Horizontal & 0.746 & 1 & 0 & 1 & 0.436 & 543 \\
\hline Payment method & Pay Method & 0.932 & 1 & 0 & 1 & 0.252 & $528^{7}$ \\
\hline Assets of the acquirer & Ln(asset) & 9.950 & 9.838 & 8.996 & 11.204 & 0.731 & 543 \\
\hline Cash flow of the acquirer & Cash Flow & 0.633 & 0.340 & -0.413 & 2.568 & 0.875 & 543 \\
\hline Excess debt of the acquirer & Excess Debt & -0.001 & 0.028 & -0.693 & 0.465 & 0.208 & 543 \\
\hline Executives'shareholding & Shareholding & 0.075 & 0.000 & 0.000 & 0.396 & 0.138 & 543 \\
\hline Investment opportunity of the acquirer & Acquirer Tobin's Q & 2.569 & 1.826 & 0.767 & 6.658 & 1.837 & 543 \\
\hline Acquisition experience & Experience & 0.173 & 0 & 0 & 1 & 0.379 & 543 \\
\hline
\end{tabular}




\begin{tabular}{|c|c|c|c|c|c|c|c|}
\hline Variable Name & Variable Symbol & Mean & Medium & Min. & Max. & Sd. & Quantity \\
\hline Year of the acquirer's establishment & Age & 14.280 & 13 & 7 & 24 & 5.326 & 543 \\
\hline Ownership property of the target company & Target SOE & 0.022 & 0 & 0 & 1 & 0.147 & 543 \\
\hline
\end{tabular}

Variables related to acquirer's characteristics are: (1) Effect Board. Jensen (1993) [31], Gertner and Kaplan (1996) [32] studied the influence of board size on corporate performance, whose conclusion is that a board of 4-12 directors is effective, help to reduce agency problem. If the board of the acquirer consist of 4-12 directors, the variable is 1 , and 0 otherwise; (2) $\mathrm{Ln}$ (asset), the natural logarithm of the acquirer's total assets at the end of the year before the merger; (3) Cash Flow, the ratio of operational cash flow and fixed assets at the end of the year before the merger; (4) Excess Debt, the asset-liability ratio of the acquirer minus the ratio of corresponding industry classified by the industry classification standard of CSRC, that is, the manufacturing industry is divided into secondary industries, and the rest of the industries are divided into primary industries, at the end of the year before the merger; (5) Shareholding, the shareholding of the General Manager, CEO, vice-GM, vice president, board secretary and other managers announced in the annual report, including executives taken by the president, at the end of the year before merger; (6) Acquirer Tobin's Q, sum of acquirer's market value and net debt divided by the sum of its book value at the end of the year prior to the M\&A; (7) Experience, which equals to 1 if the acquirer has had acquisition experience in the host country, and 0 otherwise; (8) Age, the year of establishment of the acquirer when announcing the transaction. Besides, the variable measuring the characteristics of the target company is Target SOE that equals to 1 if target company is state-owned and 0 otherwise.

Table 1 is variable descriptive statistics. This paper examines whether or not there are abnormal values according to the method of tripling standard deviation to reduce the effect of outliers on empirical results. For those variables with abnormal values, we did Winsorizaiton of $99 \%$ and $1 \%$ quantiles, replacing the value higher than the $99 \%$ quantile or lower than the $1 \%$ quantile with the $99 \%$ or $1 \%$ quantile, referring to the research of Baker et al (2003) [33]. From Table 1, (1) 136 out of 543 samples, accounting for $25 \%$, are political sensitive mergers and acquisitions of which 86 cases were for strategic resources (Strategic Resource), accounting for $15.8 \%$; 18 cases, $3.31 \%$, related to national defense (Defense Related); 19 mergers and acquisitions initiated to financial institutions (Financial Institution), holding 3.35\%; 14 mergers and acquisitions were against telecommunication suppliers (Telecommunication), making up 2.58\%; (2) 449 out of 543 samples were completed, accounting for $82.69 \%$; (3) $33.7 \%$ acquirers are state-owned, $56 \%$ of which are CGO enterprises and $44 \%$ of which are LGO enterprises.

\section{Results and Analyses}

\subsection{Influencing Factors of Cross-Border Political Sensitive Asset Transactions}

This sector explores the effect of acquirer's ownership property on acquiring political sensitive assets. We adopted Logit Model to do empirical test with the dependent variable Sensitive to represent whether there exists overseas political sensitive assets M\&A, which takes 1 for does make the transaction or 0 otherwise. The explanatory variable is acquirer's ownership property. Besides, we controlled the effect of acquirer's characteristics, include Effect Board, Ln(asset), Cash Flow, Excess Debt, Shareholding, Tobin's Q, Experience and Age, on whether make the acquisition or not.

Table 2 shows estimated results of the Logit Model. Column 1, result of the baseline regression with only control variables shows that the coefficient of $\operatorname{Ln}$ (asset) is significantly positive, which means larger-size-asset acquirer is more likely to acquire political sensitive asset while controlling other variables. And holding other variables unchanged, the coefficient of Excess Debt is significantly negative, which predicts the more asset-liability ratio of the acquirer exceeds the industry average, the less likely it is to acquire political sensitive assets, that is, over-debt constrains political sensitive assets transaction. Thirdly, the coefficient of Age is also significantly negative, which states acquiring company's long-history reduce its likelihood to acquire overseas political sensitive assets, which may due to the company's prudent operation.

Column 2, with SOE in the baseline regression, reports that the coefficient of SOE is significantly positive at $10 \%$ confidence level. Given the coefficient calculation of marginal benefit, the possibility for state-owned enterprises to implement political sensitive assets $\mathrm{M} \& \mathrm{~A}$ is $9.67 \%$ higher than that for private enterprises. When dividing SOE into CGO and LGO, it turns out that only the coefficient of CGO is significantly positive at $1 \%$ confidence level while the coefficient of LGO is not significant. Calculating the coefficient, the central government-owned enterprises is $23.12 \%$ more likely to acquire political sensitive assets than other enterprises. To sum up, the empirical results above support Hypothesis 1 and 2, that is, state-owned enterprises tend to implement overseas political sensitive assets M\&A.

Table 2. Logit regression of influences of political sensitive assets $M \& A$.

\begin{tabular}{llll}
\hline & $(\mathbf{1})$ & $(\mathbf{2})$ & $\mathbf{( 3 )}$ \\
\hline SOE & & $0.524 * *$ & \\
CGO & & $(0.260)$ & \\
& & & $1.130 * * *$ \\
LGO & & $(0.296)$ \\
& & & -0.304 \\
Effect Board & -0.490 & -0.389 & $(0.352)$ \\
& $(0.313)$ & $(0.312)$ & -0.254 \\
Ln(asset) & $0.713 * * *$ & $0.620 * * *$ & $0.325)$ \\
& $(0.201)$ & $(0.200)$ & $(0.207)$ \\
Cash Flow & -0.160 & -0.102 & -0.123 \\
& $(0.157)$ & $(0.164)$ & $(0.162)$ \\
\hline
\end{tabular}




\begin{tabular}{llll}
\hline & $(\mathbf{1})$ & $\mathbf{( 2 )}$ & $\mathbf{( 3 )}$ \\
\hline Excess Debt & $-1.103^{*}$ & $-1.324^{* *}$ & $-1.101^{*}$ \\
& $(0.605)$ & $(0.628)$ & $(0.638)$ \\
Acquirer Tobin's Q & -0.081 & -0.071 & -0.053 \\
& $(0.068)$ & $(0.067)$ & $(0.068)$ \\
Shareholding & -1.054 & -0.565 & -0.722 \\
& $(0.972)$ & $(1.027)$ & $(1.026)$ \\
Experience & 0.249 & 0.254 & 0.369 \\
& $(0.270)$ & $(0.268)$ & $(0.278)$ \\
Age & $-0.066^{* * *}$ & $-0.053^{* *}$ & $-0.048^{* *}$ \\
& $(0.021)$ & $(0.022)$ & $(0.022)$ \\
Constant & $-6.594^{* * *}$ & $-6.211^{* * *}$ & $-5.338^{* *}$ \\
& $(2.128)$ & $(2.117)$ & $(2.171)$ \\
Observations & 543 & 543 & 543 \\
Pseudo R-squared & 0.083 & 0.090 & 0.116 \\
\hline
\end{tabular}

* Statistically significant at 10 percent.

** Statistically significant at 5 percent

*** Statistically significant at 1 percent.

In parentheses, $\mathrm{t}$-statistics based on robust standard errors.

\subsection{The Influence of Political-Sensitive Acquisition on Transaction Completion}

This section studies the influence of acquiring political sensitive assets on transaction completion. We did empirical test with Logit Model and the dependent variable Completion values 1 if the acquisition was completed and 0 otherwise. The explaining variable is a dummy variable Sensitive that measures whether the target company is political sensitive asset, taking 1 or 0 . We controlled three kinds of variables, including acquirer, target company and transaction characteristics.

Table 3 presents the estimated results of Logit Model. From Column 1, it reports that the coefficient of Sensitive is significantly negative at $1 \%$. To be specific, the transaction completion probability of acquiring political sensitive assets is $12 \%$ lower than that of acquiring other assets. As for control variables, if there exist competitors (Competitive $=1$ ), the completion probability would be lower; if it is a horizontal acquiring (Horizontal=1), the actual probability would be lower, which may be due to other countries' concern on monopoly issue after M\&A; the coefficient of $\operatorname{Ln}$ (asset) is significantly positive, which states that larger company size would contribute to higher transaction completion rate; the coefficient of Excess Debt is significantly negative so excess debt would be an obstacle to M\&A transactions.

Table 3. Logit regression of influences on the completion of $M \& A$ transactions.

\begin{tabular}{lllll}
\hline & $(\mathbf{1})$ & $\mathbf{( 2 )}$ & $\mathbf{( 3 )}$ & $\mathbf{( 4 )}$ \\
\hline Sensitive & $-0.804^{* * *}$ & & & \\
& $(0.279)$ & & & \\
Strategic Resource & & $-0.872^{* * *}$ & $-0.865^{* *}$ & $-0.865^{* * *}$ \\
& & $(0.332)$ & $(0.339)$ & $(0.335)$ \\
Financial Institution & & $-1.250^{*}$ & $-1.258^{*}$ & $-1.172^{*}$ \\
& & $(0.681)$ & $(0.677)$ & $(0.674)$ \\
Defense Related & & -0.825 & -0.828 & -0.744 \\
\hline
\end{tabular}

\begin{tabular}{|c|c|c|c|c|}
\hline & (1) & (2) & (3) & (4) \\
\hline \multirow{3}{*}{ Telecommunication } & & $(0.543)$ & $(0.543)$ & $(0.556)$ \\
\hline & & -0.596 & -0.598 & -0.521 \\
\hline & & $(0.650)$ & $(0.658)$ & $(0.651)$ \\
\hline \multirow[t]{2}{*}{ CGO } & & & -0.084 & -0.076 \\
\hline & & & $(0.389)$ & $(0.378)$ \\
\hline \multirow[t]{2}{*}{ LGO } & & & -0.073 & 0.002 \\
\hline & & & $(0.391)$ & $(0.405)$ \\
\hline Pay method & & & & $\begin{array}{l}-0.335 \\
(0.542)\end{array}$ \\
\hline Competitive & $\begin{array}{l}-2.177 * * * \\
(0.453)\end{array}$ & $\begin{array}{l}-2.198 * * * \\
(0.450)\end{array}$ & $\begin{array}{l}-2.189^{* * *} \\
(0.453)\end{array}$ & $\begin{array}{l}-1.891 \text { *** } \\
(0.502)\end{array}$ \\
\hline Relatedness & $\begin{array}{l}-0.541^{*} \\
(0.293)\end{array}$ & $\begin{array}{l}-0.554^{*} \\
(0.293)\end{array}$ & $\begin{array}{l}-0.556^{*} \\
(0.292)\end{array}$ & $\begin{array}{l}-0.506^{*} \\
(0.291)\end{array}$ \\
\hline Effect Board & $\begin{array}{l}0.277 \\
(0.461)\end{array}$ & $\begin{array}{l}0.211 \\
(0.476)\end{array}$ & $\begin{array}{l}0.188 \\
(0.483)\end{array}$ & $\begin{array}{l}0.246 \\
(0.472)\end{array}$ \\
\hline Ln(asset) & $\begin{array}{l}0.712 * * * \\
(0.224)\end{array}$ & $\begin{array}{l}0.749 * * * \\
(0.230)\end{array}$ & $\begin{array}{l}0.762 * * * \\
(0.233)\end{array}$ & $\begin{array}{l}0.746^{* * *} \\
(0.234)\end{array}$ \\
\hline Cash Flow & $\begin{array}{l}0.066 \\
(0.150)\end{array}$ & $\begin{array}{l}0.075 \\
(0.150)\end{array}$ & $\begin{array}{l}0.069 \\
(0.154)\end{array}$ & $\begin{array}{l}0.098 \\
(0.159)\end{array}$ \\
\hline Excess Debt & $\begin{array}{l}-1.299^{*} \\
(0.751)\end{array}$ & $\begin{array}{l}-1.377^{*} \\
(0.775)\end{array}$ & $\begin{array}{l}-1.353 * \\
(0.781)\end{array}$ & $\begin{array}{l}-1.273^{*} \\
(0.769)\end{array}$ \\
\hline Acquirer Tobin's Q & $\begin{array}{l}-0.034 \\
(0.070)\end{array}$ & $\begin{array}{l}-0.042 \\
(0.070)\end{array}$ & $\begin{array}{l}-0.043 \\
(0.070)\end{array}$ & $\begin{array}{l}-0.041 \\
(0.073)\end{array}$ \\
\hline Shareholding & $\begin{array}{l}-0.119 \\
(0.984)\end{array}$ & $\begin{array}{l}-0.149 \\
(1.003)\end{array}$ & $\begin{array}{l}-0.206 \\
(1.045)\end{array}$ & $\begin{array}{l}-0.061 \\
(1.056)\end{array}$ \\
\hline Experience & $\begin{array}{l}0.315 \\
(0.338)\end{array}$ & $\begin{array}{l}0.308 \\
(0.337)\end{array}$ & $\begin{array}{l}0.308 \\
(0.343)\end{array}$ & $\begin{array}{l}0.251 \\
(0.341)\end{array}$ \\
\hline Target SOE & $\begin{array}{l}-1.013 \\
(0.724)\end{array}$ & $\begin{array}{l}-1.043 \\
(0.746)\end{array}$ & $\begin{array}{l}-1.024 \\
(0.745)\end{array}$ & $\begin{array}{l}-1.130 \\
(0.789)\end{array}$ \\
\hline Age & $\begin{array}{l}-0.058^{* *} \\
(0.025)\end{array}$ & $\begin{array}{l}-0.059^{* *} \\
(0.025)\end{array}$ & $\begin{array}{l}-0.061^{* *} \\
(0.026)\end{array}$ & $\begin{array}{l}-0.053^{*} \\
(0.027)\end{array}$ \\
\hline Constant & $\begin{array}{l}-4.046^{*} \\
(2.397)\end{array}$ & $\begin{array}{l}-4.282^{*} \\
(2.439)\end{array}$ & $\begin{array}{l}-4.330^{*} \\
(2.450)\end{array}$ & $\begin{array}{l}-4.127 \\
(2.517)\end{array}$ \\
\hline Observations & 541 & 541 & 541 & 526 \\
\hline Pseudo R-squared & 0.090 & 0.094 & 0.094 & 0.073 \\
\hline
\end{tabular}

* Statistically significant at 10 percent.

** Statistically significant at 5 percent.

*** Statistically significant at 1 percent.

In parentheses, t-statistics based on robust standard errors.

In Column 2, we replaced Sensitive with four dummy variables Strategic Resource, Defense Related, Financial Institution and Telecommunication in the regression. It shows the former two variables are significantly negative while the others negative but statistically insignificant. It may be accounted for the success probability discrepancy among different sensitive industries. Acquiring companies in strategic resource or financial industry has remarkable lower success rate than acquiring companies in other non-sensitive industries while the success rate of merging defense related or telecommunication industry is not significantly lower. In Column 3, the coefficients of acquirer's owner property, that is, CGO and LGO, are insignificant, which expresses that Chinese enterprises' property is no longer the adverse factor in overseas political sensitive assets M\&A with more consistent standard of outside parties. In Column 4, with the addition of the control variable Pay Method, the sample observations reduced to 526 and the results were still robust. In conclusion, 
results in Table 3 support Hypothesis 3 that if the target company is a political sensitive asset, the transaction completion rate is lower.

\subsection{The Influences of Acquiring Political Sensitive Assets on Shareholder Value}

This section investigates the influences of acquiring political sensitive assets on shareholder value. We adopted OLS Model to do the empirical test, with dependent variable CAR, explanatory variable Sensitive that takes 1 if the asset is political sensitive and 0 otherwise. We added three kinds of control variables, including acquirer, target company and transaction characteristics. From Column 1, the coefficient of Sensitive is significantly positive at $10 \%$ without adding any control variables, which states the market response is higher acquiring political sensitive assets than any other assets. Controlling other variables in Column 2, the market response of political sensitive assets M\&A is $2.1 \%$ higher than that to other kinds of M\&A, that is, acquiring cross-border political sensitive assets would create value for shareholders from the perspective of short-term market response. Additionally, the coefficient of Sensitive in Column 2 is almost twice as much as that in Column 1 with increased significance. It shows that missing control variables may be related to the variable Sensitive and market response, which makes the regression coefficient biased (small) ${ }^{8}$.

In Column 3, we replaced Sensitive with four dummy variables Strategic Resource, Defense Related, Financial Institution and Telecommunication in the regression. Given the regression of the four dummy variables, it turns out that market responses of the transaction are significantly higher with $2 \%, 3 \%$ and $5 \%$ separately when acquiring target companies related to strategic resource, finance or telecommunication than target companies related to other industries. All in all, the results shown in Column 1-3 support Hypothesis 3, that is, acquiring political sensitive assets has significantly higher market response, and create more value for shareholders.

In Column 4, we compare political sensitive assets acquired by SOEs and POEs, to see which create more value for shareholders. The variable Sensitive is multiplied by SOE, whose coefficient is significantly negative, suggests that the positive influence of acquiring political sensitive assets on shareholder value is observably weaker in SOEs than POEs. From an economic point of view, the market response of POE's overseas acquisition of political sensitive assets was $4.2 \%$ higher than the acquisition of other assets, while the market response of SOE's acquisition of politically sensitive assets was $0.7 \%[0.042+(-0.049)]$ lower than the acquisition of other assets, which supports Hypothesis 4.

\footnotetext{
8 Drawing on the analysis methods of He and Tian (2013) [34], we found that there was a significant positive correlation between the company's total assets and the dummy variable on acquiring political sensitive assets $(\rho=0.229)$, and a significant negative correlation with the market response $(\rho=-0.165)$, too. The main reason is that control this variable increases the size and significance of the dummy variable's coefficient.
}

Table 4. Regression of influences on shareholder value.

\begin{tabular}{|c|c|c|c|c|}
\hline & \multicolumn{4}{|c|}{ CAR $[-1,+1]$} \\
\hline & (1) & (2) & (3) & (4) \\
\hline \multirow[t]{2}{*}{ Sensitive } & $0.013 *$ & $0.021 * *$ & & $0.042 * * *$ \\
\hline & $(0.007)$ & $(0.008)$ & & $(0.012)$ \\
\hline \multirow[t]{2}{*}{ Strategic Resource } & & & $0.019^{*}$ & \\
\hline & & & $(0.011)$ & \\
\hline \multirow[t]{2}{*}{ Financial Institution } & & & $0.028 * *$ & \\
\hline & & & $(0.012)$ & \\
\hline \multirow[t]{2}{*}{ Defense Related } & & & 0.005 & \\
\hline & & & $(0.016)$ & \\
\hline \multirow[t]{2}{*}{ Telecommunication } & & & $0.046^{* *}$ & \\
\hline & & & $(0.019)$ & \\
\hline \multirow[t]{2}{*}{ Sensitive $\times \mathrm{SOE}$} & & & & $-0.049 * * *$ \\
\hline & & & & $(0.015)$ \\
\hline \multirow[t]{2}{*}{ SOE } & & & & 0.010 \\
\hline & & & & $(0.009)$ \\
\hline \multirow[t]{2}{*}{ Competitive } & & 0.012 & 0.012 & $0.015^{*}$ \\
\hline & & $(0.009)$ & $(0.009)$ & $(0.008)$ \\
\hline \multirow[t]{2}{*}{ Friend } & & $-0.056^{* * *}$ & $-0.056 * * *$ & $-0.067 * * *$ \\
\hline & & $(0.013)$ & $(0.013)$ & $(0.016)$ \\
\hline \multirow[t]{2}{*}{ Horizontal } & & -0.008 & -0.008 & -0.008 \\
\hline & & $(0.008)$ & $(0.008)$ & $(0.008)$ \\
\hline \multirow[t]{2}{*}{ Effect Board } & & -0.003 & -0.003 & -0.004 \\
\hline & & $(0.008)$ & $(0.008)$ & $(0.008)$ \\
\hline \multirow[t]{2}{*}{ Ln(asset) } & & $-0.025 * * *$ & $-0.026 * * *$ & $-0.021 * * *$ \\
\hline & & $(0.006)$ & $(0.006)$ & $(0.006)$ \\
\hline \multirow[t]{2}{*}{ Cash Flow } & & $-0.009 * *$ & $-0.009 * *$ & $-0.008^{*}$ \\
\hline & & $(0.004)$ & $(0.004)$ & $(0.005)$ \\
\hline \multirow[t]{2}{*}{ Excess Debt } & & 0.002 & 0.003 & 0.002 \\
\hline & & $(0.015)$ & $(0.015)$ & $(0.015)$ \\
\hline \multirow[t]{2}{*}{ Acquirer Tobin's Q } & & -0.000 & -0.000 & -0.001 \\
\hline & & $(0.002)$ & $(0.002)$ & $(0.002)$ \\
\hline \multirow[t]{2}{*}{ Shareholding } & & -0.025 & -0.029 & -0.021 \\
\hline & & $(0.029)$ & $(0.029)$ & $(0.030)$ \\
\hline \multirow[t]{2}{*}{ Experience } & & 0.013 & 0.013 & 0.013 \\
\hline & & $(0.008)$ & $(0.008)$ & $(0.008)$ \\
\hline \multirow[t]{2}{*}{ Target SOE } & & 0.017 & 0.013 & 0.019 \\
\hline & & $(0.023)$ & $(0.023)$ & $(0.021)$ \\
\hline \multirow[t]{2}{*}{ Toehold } & & 0.053 & 0.057 & 0.060 \\
\hline & & $(0.046)$ & $(0.046)$ & $(0.047)$ \\
\hline \multirow[t]{2}{*}{ Age } & & -0.000 & -0.000 & -0.001 \\
\hline & & $(0.001)$ & $(0.001)$ & $(0.001)$ \\
\hline \multirow[t]{2}{*}{ Pay method } & & -0.015 & -0.016 & -0.016 \\
\hline & & $(0.012)$ & $(0.013)$ & $(0.012)$ \\
\hline \multirow[t]{2}{*}{ Constant } & $0.014 * * *$ & $0.295 * * *$ & $0.304 * * *$ & $0.256 * * *$ \\
\hline & $(0.004)$ & $(0.066)$ & $(0.068)$ & $(0.067)$ \\
\hline Observations & 540 & 525 & 525 & 525 \\
\hline R-squared & 0.006 & 0.079 & 0.083 & 0.096 \\
\hline
\end{tabular}

* Statistically significant at 10 percent.

** Statistically significant at 5 percent.

*** Statistically significant at 1 percent.

In parentheses, $\mathrm{t}$-statistics based on robust standard errors.

\subsection{Robustness Tests}

We did the following two robustness check.

First, we replaced market response $(\mathrm{CAR}[-1,+1])$ with $\mathrm{CAR}[-5,+5]$, the cumulative abnormal return of 11 trading day 
before and after the first acquisition announcement, to do the re-regression of Table 4 . And results turn out to be robust still.

Table 5. Robustness test of the regression of influences on shareholder value.

\begin{tabular}{|c|c|c|c|c|}
\hline & \multicolumn{4}{|c|}{ CAR $[-5,+5]$} \\
\hline & (1) & (2) & (3) & (4) \\
\hline Sensitive & $\begin{array}{l}0.017 \\
(0.013)\end{array}$ & $\begin{array}{l}0.029 * \\
(0.015)\end{array}$ & & $\begin{array}{l}0.055 * * \\
(0.022)\end{array}$ \\
\hline Strategic Resource & & & $\begin{array}{l}0.017 \\
(0.018)\end{array}$ & \\
\hline Financial Institution & & & $\begin{array}{l}0.077 * * \\
(0.033)\end{array}$ & \\
\hline Defense Related & & & $\begin{array}{l}0.029 \\
(0.043)\end{array}$ & \\
\hline Telecommunication & & & $0.042 *$ & \\
\hline Sensitive $\times$ SOE & & & $(0.024)$ & $-0.064 * *$ \\
\hline SOE & & & & $\begin{array}{l}(0.028) \\
0.017 \\
(0.018)\end{array}$ \\
\hline Competitive & & $\begin{array}{l}-0.001 \\
(0.018)\end{array}$ & $\begin{array}{l}0.001 \\
(0.018)\end{array}$ & $\begin{array}{l}0.003 \\
(0.018)\end{array}$ \\
\hline Friend & & $\begin{array}{l}-0.094 * * \\
(0.037)\end{array}$ & $\begin{array}{l}-0.095 \text { *** } \\
(0.035)\end{array}$ & $\begin{array}{l}-0.109 * * * \\
(0.041)\end{array}$ \\
\hline Horizontal & & $\begin{array}{l}-0.039 * * \\
(0.016)\end{array}$ & $\begin{array}{l}-0.041 * * \\
(0.016)\end{array}$ & $\begin{array}{l}-0.039 * * \\
(0.016)\end{array}$ \\
\hline Effect Board & & $\begin{array}{l}-0.005 \\
(0.016)\end{array}$ & $\begin{array}{l}0.000 \\
(0.017)\end{array}$ & $\begin{array}{l}-0.006 \\
(0.017)\end{array}$ \\
\hline Ln(asset) & & $\begin{array}{l}-0.038^{* * *} \\
(0.013)\end{array}$ & $\begin{array}{l}-0.040 * * * \\
(0.013)\end{array}$ & $\begin{array}{l}-0.033 * * \\
(0.013)\end{array}$ \\
\hline Cash Flow & & $\begin{array}{l}-0.008 \\
(0.007)\end{array}$ & $\begin{array}{l}-0.010 \\
(0.006)\end{array}$ & $\begin{array}{l}-0.007 \\
(0.007)\end{array}$ \\
\hline Excess Debt & & 0.033 & 0.031 & 0.031 \\
\hline
\end{tabular}

\begin{tabular}{|c|c|c|c|c|}
\hline & \multicolumn{4}{|c|}{$\operatorname{CAR}[-5,+5]$} \\
\hline & (1) & (2) & (3) & (4) \\
\hline \multirow{3}{*}{ Acquirer Tobin's Q } & & $(0.033)$ & $(0.033)$ & $(0.035)$ \\
\hline & & $-0.008 * *$ & $-0.008 * *$ & $-0.008 * *$ \\
\hline & & $(0.003)$ & $(0.003)$ & $(0.003)$ \\
\hline \multirow[t]{2}{*}{ Shareholding } & & -0.013 & -0.018 & -0.004 \\
\hline & & $(0.049)$ & $(0.049)$ & $(0.051)$ \\
\hline \multirow[t]{2}{*}{ Experience } & & 0.014 & 0.017 & 0.014 \\
\hline & & $(0.015)$ & $(0.015)$ & $(0.015)$ \\
\hline \multirow[t]{2}{*}{ Target SOE } & & 0.037 & 0.034 & 0.039 \\
\hline & & $(0.040)$ & $(0.039)$ & $(0.036)$ \\
\hline \multirow[t]{2}{*}{ Toehold } & & 0.115 & 0.128 & 0.125 \\
\hline & & $(0.126)$ & $(0.123)$ & $(0.126)$ \\
\hline \multirow[t]{2}{*}{ Age } & & -0.002 & -0.002 & $-0.003^{*}$ \\
\hline & & $(0.001)$ & $(0.001)$ & $(0.001)$ \\
\hline \multirow[t]{2}{*}{ Pay method } & & -0.028 & -0.031 & -0.029 \\
\hline & & $(0.023)$ & $(0.023)$ & $(0.023)$ \\
\hline \multirow[t]{2}{*}{ Constant } & $0.025^{* * *}$ & $0.515^{* * *}$ & $0.529 * * *$ & $0.466^{* * *}$ \\
\hline & $(0.007)$ & $(0.145)$ & $(0.146)$ & $(0.149)$ \\
\hline Observations & 538 & 525 & 525 & 525 \\
\hline R-squared & 0.003 & 0.076 & 0.081 & 0.085 \\
\hline
\end{tabular}

* Statistically significant at 10 percent.

** Statistically significant at 5 percent.

*** Statistically significant at 1 percent.

In parentheses, t-statistics based on robust standard errors.

Secondly, we also examined the effect of acquirer's age on regressions. In Table 6, we separated the sample into two groups, one established more than 13 years (the median number), and the other less than 13 years, to regress as Table 3 and 4 separately, whose results are robust as before.

Table 6. Robustness test of effect of acquirer's age on empirical results.

\begin{tabular}{|c|c|c|c|c|}
\hline & (1) & (2) & (3) & (4) \\
\hline \multirow[t]{2}{*}{ Dependent variable } & Completion & Completion & $\mathrm{CAR}[-1,+1]$ & $\operatorname{CAR}[-1,+1]$ \\
\hline & Short establishment period & Long establishment period & Short establishment period & Long establishment period \\
\hline \multirow[t]{2}{*}{ Sensitive } & $-0.659 *$ & $-1.042 * *$ & $0.022 *$ & $0.023 * *$ \\
\hline & $(0.367)$ & $(0.465)$ & $(0.013)$ & $(0.010)$ \\
\hline Controls & Yes & Yes & Yes & Yes \\
\hline Observations & 302 & 237 & 246 & 279 \\
\hline R-squared & 0.104 & 0.098 & 0.091 & 0.136 \\
\hline
\end{tabular}

\subsection{Solution of Endogenous Problems}

In this section, we further considered the endogenous problems that may exist in Table 3 and 4's models. To be specific, the correlation between dummy variable Sensitive and transaction completion (or shareholder value) may results from leaving out some other control variables that possibly affect both enterprises acquiring political sensitive assets and transaction completion (or shareholder value) to a "pseudo-correlation" between the two. We used Instrumental Variables to solve the endogenous problems. We picked the dummy variable of acquirer's executive political connection (Political Connection) as the instrumental variable. Based on the method to measure political connection of a company given by Calomiris et al (2010) [35], it is taken into consideration that whether the chairman or CEO has ever held a position at or above the level of deputy mayor or not. The variable values 1 if yes, and 0 otherwise. The reason of choosing this instrumental variable is politically-connected chairman or CEO are more likely to be effected by government goals and global strategic layout so as to increase the possibility to acquire political sensitive assets mergers and acquisitions.

In Table 7, we adopted Instrumental Variable (IV) method to re-examine the influences of acquiring political sensitive assets on transaction completion. Column 1 presents results of the first stage regression of instrumental variable method. It shows the influences of Political Connection on whether acquiring political sensitive assets is significantly positive at $1 \%$. The Parital-F value of the first stage regression is 19.89 , higher than the threshold value 8.96 offered by Stock, et al 
(2002) [36], which illustrates the instrumental variable is not weak. Besides, Column 2 lists the results of the second stage regression, basically same as the regression results in Table 3, which shows that political sensitive assets acquisitions still has a negative impact transaction completion and further supports Hypothesis 3, after controlling endogenous problems.

Table 7. Regression of IV affecting political-sensitive acquisition on transaction completion.

\begin{tabular}{|c|c|c|}
\hline \multirow{2}{*}{ VARIABLES } & (1) & (2) \\
\hline & Sensitive & Completion \\
\hline \multirow[t]{2}{*}{ IV-Political connection } & $0.252 * * *$ & \\
\hline & $(0.049)$ & \\
\hline \multirow[t]{2}{*}{ Sensitive } & & $-0.394 * *$ \\
\hline & & $(0.185)$ \\
\hline \multirow[t]{2}{*}{ Competitive } & -0.024 & $-0.392 * * *$ \\
\hline & $(0.085)$ & $(0.095)$ \\
\hline \multirow[t]{2}{*}{ Relatedness } & 0.020 & -0.062 \\
\hline & $(0.041)$ & $(0.038)$ \\
\hline \multirow[t]{2}{*}{ Effect Board } & -0.068 & 0.008 \\
\hline & $(0.061)$ & $(0.061)$ \\
\hline \multirow[t]{2}{*}{ Ln(asset) } & $0.066^{*}$ & $0.127 * * *$ \\
\hline & $(0.034)$ & $(0.039)$ \\
\hline \multirow[t]{2}{*}{ Cash Flow } & -0.009 & -0.000 \\
\hline & $(0.022)$ & $(0.021)$ \\
\hline \multirow[t]{2}{*}{ Excess Debt } & $-0.209 * *$ & $-0.226 * *$ \\
\hline & $(0.096)$ & $(0.107)$ \\
\hline \multirow[t]{2}{*}{ Acquirer Tobin's Q } & -0.006 & -0.009 \\
\hline & $(0.011)$ & $(0.010)$ \\
\hline \multirow[t]{2}{*}{ Shareholding } & -0.083 & -0.050 \\
\hline & $(0.146)$ & $(0.149)$ \\
\hline \multirow[t]{2}{*}{ Experience } & 0.060 & 0.052 \\
\hline & $(0.047)$ & $(0.044)$ \\
\hline \multirow[t]{2}{*}{ Target SOE } & $0.353 * * *$ & -0.057 \\
\hline & $(0.121)$ & $(0.163)$ \\
\hline \multirow[t]{2}{*}{ Age } & $-0.007 *$ & $-0.011 * * *$ \\
\hline & $(0.004)$ & $(0.004)$ \\
\hline \multirow[t]{2}{*}{ Constant } & -0.320 & -0.100 \\
\hline & $(0.351)$ & $(0.364)$ \\
\hline Observations & 541 & 541 \\
\hline R-squared/F-value & 0.156 & $3.74 * * *$ \\
\hline Partial-F & $19.89(\mathrm{p}<0.001)$ & \\
\hline
\end{tabular}

* Statistically significant at 10 percent.

** Statistically significant at 5 percent.

*** Statistically significant at 1 percent.

In parentheses, t-statistics based on robust standard errors.

In Table 8, we re-tests the impact of acquiring political sensitive assets on market response by instrumental variable method. Column 1 lists results of the first stage regression, showing there is significantly positive impact on acquiring political sensitive assets. The instrumental variable is not weak since the Parital-F value is 17.83 , higher than the threshold value 8.96 offered by Stock, et al (2002) [36]. The results of the second stage of regression are listed in Column 2 and 3, which are basically consistent to the results showed in
Table 4 and 5. It means acquiring political sensitive assets has notable positive effects on the market response both 3 $(\mathrm{CAR}[-1,+1])$ and $11(\mathrm{CAR}[-5,+5])$ trading days before and after the first announcement day, which backs up Hypothesis 4 in another way.

Table 8. Regression of IV affecting political sensitive acquisition on shareholder value.

\begin{tabular}{|c|c|c|c|}
\hline & (1) & (2) & (3) \\
\hline & Sensitive & CAR $[-1,+1]$ & CAR $[-5,+5]$ \\
\hline \multirow[t]{2}{*}{ IV-Political connection } & $0.243 * * *$ & & \\
\hline & $(0.057)$ & & \\
\hline \multirow[t]{2}{*}{ Sensitive } & & $0.088^{*}$ & $0.160 *$ \\
\hline & & $(0.064)$ & $(0.064)$ \\
\hline \multirow[t]{2}{*}{ Competitive } & -0.041 & 0.013 & 0.001 \\
\hline & $(0.090)$ & $(0.297)$ & $(0.951)$ \\
\hline \multirow[t]{2}{*}{ Friend } & 0.221 & $-0.076^{* *}$ & $-0.134 *$ \\
\hline & $(0.304)$ & $(0.012)$ & $(0.061)$ \\
\hline \multirow[t]{2}{*}{ Horizontal } & 0.014 & -0.009 & $-0.040 * *$ \\
\hline & $(0.044)$ & $(0.314)$ & $(0.018)$ \\
\hline \multirow[t]{2}{*}{ Effect Board } & -0.067 & 0.005 & 0.011 \\
\hline & $(0.070)$ & $(0.653)$ & $(0.621)$ \\
\hline \multirow[t]{2}{*}{ Ln(asset) } & $0.072 *$ & $-0.033 * * *$ & $-0.055 * * *$ \\
\hline & $(0.037)$ & $(0.000)$ & $(0.001)$ \\
\hline \multirow[t]{2}{*}{ Cash Flow } & -0.006 & -0.007 & -0.006 \\
\hline & $(0.026)$ & $(0.104)$ & $(0.443)$ \\
\hline \multirow[t]{2}{*}{ Excess Debt } & $-0.217 * *$ & 0.016 & 0.062 \\
\hline & $(0.106)$ & $(0.401)$ & $(0.114)$ \\
\hline \multirow[t]{2}{*}{ Acquirer Tobin's Q } & -0.004 & 0.000 & $-0.007 *$ \\
\hline & $(0.011)$ & $(0.862)$ & $(0.069)$ \\
\hline \multirow[t]{2}{*}{ Shareholding } & -0.078 & -0.014 & 0.008 \\
\hline & $(0.138)$ & $(0.659)$ & $(0.889)$ \\
\hline \multirow[t]{2}{*}{ Experience } & 0.073 & 0.009 & 0.006 \\
\hline & $(0.050)$ & $(0.371)$ & $(0.750)$ \\
\hline \multirow[t]{2}{*}{ Target SOE } & $0.323 * *$ & -0.009 & -0.013 \\
\hline & $(0.157)$ & $(0.793)$ & $(0.816)$ \\
\hline \multirow[t]{2}{*}{ Toehold } & -0.003 & 0.001 & 0.002 \\
\hline & $(0.004)$ & $(0.240)$ & $(0.314)$ \\
\hline \multirow[t]{2}{*}{ Age } & $-0.007 *$ & 0.000 & -0.001 \\
\hline & $(0.004)$ & $(0.731)$ & $(0.686)$ \\
\hline \multirow[t]{2}{*}{ Pay method } & -0.085 & -0.010 & -0.018 \\
\hline & $(0.070)$ & $(0.490)$ & $(0.542)$ \\
\hline \multirow[t]{2}{*}{ Constant } & -0.303 & $0.336 * * *$ & $0.596 * * *$ \\
\hline & $(0.388)$ & $(0.000)$ & $(0.000)$ \\
\hline Observations & 525 & 525 & 525 \\
\hline R-squared/F-value & 0.149 & $2.30 * * *$ & $1.75^{* *}$ \\
\hline Partial-F & $17.83(\mathrm{p}<0.001)$ & & \\
\hline
\end{tabular}

* Statistically significant at 10 percent.

** Statistically significant at 5 percent.

*** Statistically significant at 1 percent.

In parentheses, $\mathrm{t}$-statistics based on robust standard errors.

\section{Conclusions and Inspirations}

This paper draws conclusions as follows by systematically studying transaction completion and financial performance of Chinese companies' cross-border political sensitive assets 
mergers and acquisitions, with the sample of 543 transactions made in 2000-2014. Firstly, central government-owned enterprises are more likely to acquire cross-border political sensitive assets than local government-owned enterprises and private companies. Secondly, under the circumstance that foreign governments have successively legislated to limit foreign capital investment and M\&A activities in some politically sensitive industries, the completion rate of Chinese companies acquiring cross-border political sensitive assets is $12 \%$ lower than acquiring other kinds of assets. Thirdly, market response is $2.1 \%$ higher when acquiring political sensitive assets than other assets, which means acquiring overseas political sensitive assets is helpful for Chinese companies to increase shareholder value. At last, the positive impact on shareholder value is weaker in state-owned enterprises than in private companies when acquiring political sensitive assets.

The research conclusions of this paper have important implications for Chinese companies to implement overseas mergers and acquisitions. To begin with, the recovery of global economy was weak after the global financial crisis in $2008^{9}$, while Chinese economy maintained a steady and rapid development. In this case, it has become consensus for domestic business that Chinese companies should implement cross-border mergers and acquisitions and process the global layout which contributes to increase shareholder value. But it still remains a puzzle that how to implement overseas M\&A strategy. To be specific, such as which industry to focus on, which method to take and what principles to adhere to can enhance their international competitiveness to a greater extent, confuse those Chinese companies that are implementing "going out" strategy. This paper finds that although the acquisition of political sensitive assets by Chinese companies is even less successful, once successful, it will be beneficial to increase the value of the company, especially for private enterprises. Therefore, Chinese companies should focus more on those overseas transactions that are aiming to obtain political sensitive assets such as resources and advanced technologies in strategy planning. Secondly, Chinese government should promptly launch corresponding checks and balances while facing increasingly severe foreign-invested security review systems in countries around the world. For example, takes corresponding executive actions to foreign companies when they acquire Chinese companies to impede foreign government so as to protect legitimate interests of domestic companies in internationalization process.

\section{Acknowledgements}

Shi Li gratefully acknowledges financial support from the National Natural Science Foundation of China (Grant 71402156) and XNAI Research Fund.

9 Xie, Shi and Zhang (2016) [37] inspects the way of governments and companies formulating optimal strategic trade policies in the context of the post-financial crisis and the global economic slowdown.

\section{References}

[1] Zhang, J.H., Wei, X.J. and Eberts, H. “Analysis of the Factors Determining the Success or Failure of Chinese Enterprises' Overseas Acquisitions.” 2010, 03, pp. 97-107.

[2] Li, R. "The Analysis of Technology-seeking Incentive in Transnational M\&A." The Journal of World Economy, 2003,02, pp. 19-24, 79.

[3] Yu, K.L. and Wang, T.M. "The Influence of Open Innovation Based on M\&As on Independent Innovation of Enterprises: Experience and General Implications Nanjing Auto Merging Rover." Management World, 2008, 04, pp. 150-159,166.

[4] Shao, X.J., Wu, H.M., Xiao, L.S., Yang, J. and Xue, Y. "The Strategic Goal and Performance of Chinese Enterprises' Cross-border M\&As: Based on A-share Market Evaluation." The Journal of World Economy, 2012, 35(05), pp. 81-105.

[5] Erel, I.; Liao, R. C. And Weisbach, M. S. "Determinants of Cross-Border Mergers and Acquisitions." Journal of Finance, 2012, 67(3), pp. 1045-1082.

[6] Gu, L.L. and Reed, R. "Do Chinese Acquirers Fail in Overseas M \& As?” Economic Research Journal, 2011, 46(07), pp. 116-129.

[7] Baker, M.; Foley, C. F. and Wurgler, J. "Multinationals As Arbitrageurs: The Effect Of Stock Market Valuations On Foreign Direct Investment.” Review of Financial Studies, 2008, 22(1), pp. 337-369.

[8] Moeller, S. B. and Schlingemann, F. P. "Global Diversification and Bidder Gains: A Comparison between Cross-Border and Domestic Acquisitions.” Journal of Banking \& Finance, 2005, 29(3), pp. 533-564.

[9] Dikova, D.; Sahib P. R. and Witteloostuijn A. V. "Cross-Border Acquisition Abandonment and Completion: The Effect of Institutional Differences and Organizational Learning in the International Business Service Industry, 1981-2001.” Journal of International Business Studies, 2010, 41(2), pp. 223-245.

[10] Buckley, P. J.; Clegg, L. J.; Cross, A. R.; Xin, L.; Voss, H. and Ping, Z. "The Determinants of Chinese Outward Foreign Direct Investment." Journal of International Business Studies, 2007, 38(4), pp. 499-518.

[11] Zhang, J.H. and Zhou, C.H. "A Study on Institutional Barriers of Chinese Companies Going Global.” Economic Research Journal, 2010, 45(06), pp. 80-91, 119.

[12] Desai, M. A.; Foley, C. F. and Hines, J. R. "Capital Controls, Liberalizations, and Foreign Direct Investment." Review of Financial Studies, 2006, 19(4), pp.1433-1464.

[13] Ahern, K. R.; Daminelli, D. and Fracassi, C. "Lost in Translation? The Effect of Cultural Values on Mergers around the World." Journal of Financial Economics, 2015, 117 (1), pp. 165-189.

[14] Ferreira, M. A.; Massa, M. and Matos, P. P. "Shareholders at the Gate? Institutional Investors and Cross-Border Mergers and Acquisitions." Review of Financial Studies, 2010, 23(2), pp. 601-644.

[15] Bris, A. and Cabolis. C. "The Value of Investor Protection: Firm Evidence from Cross-Border Mergers." Review of Financial Studies, 2008, 21(2), pp. 605-648. 
[16] Cheng, H.F. and Zhang, K.Y. "The Analysis of the Wealth Effect of Chinese Listed Companies' Cross-border Mergers." The Journal of World Economy, 2006, 12, pp. 74-80.

[17] Gugler, K.; Mueller, D. C.; Yurtoglu, B. B. and Zulehner, C. "The Effects of Mergers: An International Comparison." International Journal of Industrial Organization, 2003, 21(5), pp.625-653.

[18] Stiglitz, J. E. and Weiss, A. "Credit Rationing in Markets with Imperfect Information.” American Economic Review, 1981, 71, pp. 393-410.

[19] Greenwald, B. and Stiglitz, J. E. "Externalities in Economies with Imperfect Information and Incomplete Markets." Quarterly Journal of Economics, 1986, 101, pp. 229-264.

[20] Shleifer, A. and Visnhy, R. W. "Politicians and Firms." Quarterly Journal of Economics, 1994, 109(4), pp. 995-1025.

[21] Shleifer, A. and Visnhy, R. W. "Politicians and Firms." Quarterly Journal of Economics, 1994, 109(4), pp. 995-1025.

[22] Chen, X.Y. and Huang, J. "Government Intervention, Diversification and Corporate Performance." Management World, 2007, 01, pp. 92-97.

[23] Alon I. and McIntyre, J. R. eds. Globalization of Chinese enterprises. London: Palgrave Macmillan, 2008.

[24] Rui, H. and Yip, G. S. "Foreign Acquisitions by Chinese Firms: A Strategic Intent Perspectives." Journal of World Business, 2008, 43(2), pp. 213-226.

[25] Globerman, S. and Shapiro, D. "Economic and Strategic Considerations Surrounding Chinese FDI in the United States." Asia Pacific Journal of Management, 2009, 26(1), pp. 163-183.

[26] Higgins, M. J. and Rodriguez, D. "The Outsourcing of R\&D through Acquisitions in the Pharmaceutical Industry." Journal of Financial Economics, 2006, 80(2), pp. 351-383.

[27] Hoberg, G. and Phillips, G. "Product Market Synergies and Competition in Mergers and Acquisitions: A Text-Based Analysis." Review of Financial Studies, 2010, 23, pp. 3773-3811.
[28] Zhang, X. "Do Mergers and Acquisitions Create Value: Evidence from Chinese Listed Companies." Economic Research Journal, 2003, 06, pp. 20-29, 93.

[29] Karolyi, G. A. and Liao, R. C. "What is Different about Government-Controlled Acquirers in Cross-Border Acquisitions?” AFA Denver Meeting Paper, 2010.

[30] Bruner, R. F. Applied Mergers and Acquisitions. New York: John Wiley \& Sons, 2004.

[31] Jensen, M. C. "The Modern Industrial Revolution, Exit, and the Failure of Internal Control Systems.” Journal of Finance, 1993, 48(3), pp. 831-880.

[32] Gertner, R. and Kaplan, S. The Value-Maximizing Board. University of Chicago Working Paper, 1996.

[33] Baker, M.; Stein, J. and Wurgler, J. "When does the Market Matter? Stock Prices and the Investment of Equity-dependent Firms." Quarterly Journal of Economics, 2003, 118(3), pp. 969-1005.

[34] He, J. and Tian, X. "The Dark Side of Analyst Coverage: The Case of Innovation." Journal of Financial Economics, 2013, 109 , pp. 856-878.

[35] Calomiris, C.; Fisman, R. and Wang, Y. "Profiting from Government Stakes in a Command Economy: Evidence from Chinese Asset Sales.” Journal of Financial Economics, 2010, 96(3), pp. 399-412.

[36] Stock, J. H., Wright, J. H. and Yogo, M. "A Survey of Weak Instruments and Weak Identification in Generalized Method of Moments.” Journal of Business \& Economics Statistics, 2002, 20(4), pp. 518-529.

[37] Xie, S.X., Shi, H.M. and Zhang, M.X. "The Bargaining Power and Strategic Trade Policies." The Journal of World Economy, 2016, 39(07), pp. 3-23. 